\title{
A Global Dialogue on Learning and Studying
}

\author{
Weili Zhao ${ }^{1} \cdot$ Derek R. Ford $^{2} \cdot$ Tyson E. Lewis $^{3}$
}

Published online: 13 March 2020

(c) Springer Nature B.V. 2020

In the book, On Study: Giorgio Agamben and Educational Potentiality (2013), Tyson E. Lewis observed that studying is perhaps best done in the company of friends. While the historical cliché of study is that it is a lone practice, done in solitude, Lewis argues that the "study of" is always already a kind of "study with." This special issue is partly inspired by an ongoing, inter-cultural "study with" among the co-editors on and beyond the topic of study over the past few years. For example, Derek Ford's examinations of the politics of air and study have encountered with Weili Zhao's unpacking of the Chinese "wind" pedagogy toward a materialist sphereology (Ford and Zhao 2018) and a Daoist study of affect (Zhao and Ford 2018), while both Ford and Lewis have grappled with the relationship between studying, political activist, and communist theory (Ford 2016; Lewis 2017). In turn, Lewis's meditations on study and inoperative learning as a weak philosophy overcoming the strong philosophy of learning resonated with Zhao's daoist sensibility that the weak can indeed beat the strong by a yin-yang movement (Zhao 2019a). Studying with each other's work through publications, conferences, and general dialogue, we've encountered unanticipated wonderment in re-imagining and further opening forms of study and learning to the unexplored. As an extension, we hoped to invoke a global dialogue, explicating further so-far underappreciated onto-epistemic sensibilities on learning, unlearning, and studying. This special issue embodies our effort, bringing together seven new imaginations and theorizations on studying and learning that address a wide range of topics from a variety of approaches.

For this brief introduction, we would like to first offer a genealogical overview of the development of the concept of study before briefly comparing learning and studying as two educational formations, questioning whether we can place them into a binary opposition. While study can be conceptualized variously as alternative or oppositional to the learning formation, the relationship between the two should itself remain open to further study.

Weili Zhao

weilizhao18@cuhk.edu.hk

Derek R. Ford

derekford@depauw.edu

Tyson E. Lewis

Tyson.Lewis@unt.edu

1 The Chinese University of Hong Kong, Shatin, Hong Kong SAR, People's Republic of China

2 Depauw University, Greencastle, USA

3 University of North Texas, Denton, USA 
Nor are these two the only exhaustive formations of education. Indeed, our gambit in this collection is that studying with others through inter-cultural philosophical inquiry offers a unique moment for rethinking the multiple and fluid relations between studying, learning, and other educational forms of engagement as they merge and diverge, multiply and divide. In conclusion, we give an overview of the seven pieces as well as new horizons for further inter-cultural explorations and dialogues on learning and studying.

\section{A Genealogical Overview}

As Lewis (2018a, b) argues elsewhere, study has a long trajectory with genealogical origins in Montaigne's mental wanderings in Essays or Rousseau's Reveries of the Solitary Walker, both of which embraced the distraction, wayfaring, and meandering deviations of study over and above a single-minded focus on producing tangible results. For both, study offered a unique educational form of life that was not reducible to learning that places an accent on attention, productivity, and ends over means. Despite their insights, such voices have remained marginal in the educational canon, often dismissed as romantically escapist or (even worse) elitist. Then, in 1971, Robert McClintock published the seminal essay titled "Toward a Place for Study in a World of Instruction." McClintock foresaw an educational landscape dominated by teaching and learning, leaving little time or place for study to happen. Like those before him, McClintock's prophecy remained largely unheeded, but with the increasingly hegemonic power of the discourses of learning, or the "learnification" (Biesta 2005) of education, it seems that a turn to study is now more urgent than ever.

Insurgent calls for study as an educational form of life that is collective, debt-free, and resistant to administration, measurement, and ideologies of productivity have suddenly appeared in multiple forms of scholarship. For instance, Arsenjuk and Koerner (2009) have argued against the categorization of the student as a depoliticized educational consumer and/or indentured servant subjected to various administrative and managerial discourses and practices of learning. Instead, they called for a renewed struggle for study as an unprofessional activity. In The Undercommons: Fugitive Planning \& Black Study (2013), Stefano Harney and Fred Moten highlighted the importance of subaltern educational practices that suspend the logic of debt that supports neoliberal university structures and return education to free use via collective study. That same year, Lewis published On Study: Giorgio Agamben and Educational Potentiality, which was the first comprehensive conceptualization of the unique ontological, political, aesthetic, temporal, and collective nature of study in philosophy of education. It is important to highlight the simultaneousness of these independent turns toward study to address the poverty of educational life under neoliberalism and the clear, overwhelming desire to produce alternatives.

Afterwards, study as a concept has continued to appear in educational philosophy and theory as a topic of concern and gradually this occurred on a global landscape. Here, we can cite Samuel Rocha's phenomenology of study (2015), Joris Vliegh's embodied practicing as an offshoot of studying (2016), Michael Murphy's active learning as a kind of study (2020), as well as the important volume edited by Claudia W. Ruitenberg, Reconceptualizing Study in Educational Discourse and Practice (2017). The latter provides a rich dialogue on study among scholars working in Canada, the United States, the United Kingdom, Belgium, Spain, and with ties to Ireland, the Netherlands, and Chile (albeit lacking voices from Asia, Africa, and Indigenous Scholars in the America) (p. 4). Also of note are experiments in the politics of study practiced and theorized by Derek Ford, who proposes 
a notion of communist study as an educational activity with an intrinsic relationship to the production of the common (Ford 2016). Identifying the importance of studying in the historical and ongoing practices of communist organizing (Ford 2017a, b), Ford has worked to tease out the contradictions between politics and education, and their various relationships with means and ends, binaries and multiplicities, potentiality and actuality, openness and direction (Ford 2018, 2019).

Lewis has furthered his theory of studying together with many friends that have taken the form of essays on the studious university (Backer and Lewis 2015), studious research (D'Hoest and Lewis 2015), the studious potentiality of philosophical dialogue in classrooms (Jasinski and Lewis 2015), the possible use of digital platforms for study (AliRezaBeigi and Lewis 2018), and tinkering as the rhythm of study (Lewis and Friedrich 2016). In 2018, Lewis published his book Inoperative learning: A radical rewriting of educational potentialities where he explicates the varied forms of inoperative learning in the fields of child development, teaching, learning, the school, the human, sociological research, and teacher education. In 2018, Lewis was also a guest editor for a special issue dedicated to study and the arts for the journal Visual Arts Research.

As a gesture to further internationalize study scholarship, Weili Zhao has juxtaposed study with Daoist wisdom in a few articles. She reviewed Ford's Communist Study and Lewis's Inoperative Learning from the daoist yin-yang thesis (Zhao 2017, 2019a). Specifically, Zhao leverages upon the bipolar yin-yang dynamic to re-envision study and learning into a movement rather than a binary pair, corroborating with the collective "study with" insights suggested by Ford and Lewis. In a co-authored paper, Zhao and Ford (2018) dialogued Western affect theory with Daoist story-telling pedagogy to envision a Daoist forgetting as an affective mode of study. Zhao (2019b) further proposed a "Daoist ontoun-learning" as a non-individualistic and non-anthropocentric Eastern form of study to implode the modern presumption of learner as a rational and autonomous individual. In this special issue, Zhao recalibrates study and learning as two hermeneutic principles that can be correlated to Greco-Christian seeing, Rabbinic hearing, and the Chinese Yijing observing for new openings.

\section{Caution Against Ordering Study and Learning as a Binary Pair}

A continual concern in the scholarship on studying is its relationship with learning. While the above various perspectives on studying may have different expressions, what they all agree on is that the logic of learning is not sufficient for articulating the whole of education and study is (in some way) envisioned as an alternative to the learning logic. Please note here alternative is not equal to oppositional but different. Placing study and learning into a binary opposition is not only reductive, but also reminiscent of the Western substance ontology. However, as Ford (2016) maintains, study happens all the time in the secret and fluid undercommons and often in the form of collective study with. He explicitly re-constellates learning and studying beyond the binary division as a fluid space of figural education that points to the excessive secret life of the studier that is not reducible to either learning or studying. Lewis (2018a, b) describes the temporality of his weak study philosophy as being thoroughly modern, not in the sense of being perfectly coeval with the present or projected to a future but as a "small temporal gap" (Agamben 2015, p. 173), "a tiny shift within the actual that re-potentiates the actual by suspending it from within" (Lewis 2018a, 
b, p. 9). In other words, inoperative learning and study happen with the temporal "noncoincidence that exists within each moment right now" (ibid.).

In this light, even though dominant learning oftentimes silences and subsumes the alternative practices of studying, the latter can be and indeed are released from the former any minute. Or put in a better way, since learning and studying can both happen at all times and spaces, one key question concerns the possibility of rendering the dominance of learning practices inoperative to provide a clearing for the study practices to show themselves as they are. Zhao (2019b) for example, re-envisions study and learning as two yin-yang elements entangled within a perpetual dao movement. Both elements happen all the time, and it is just that one becomes dominant over the other at certain moments. In the current neoliberal society, for example, the yang-learning element dominates-marginalizes the yinstudy element to the point that the yin-yang movement becomes almost stagnant and people no longer easily see the happening of study. To go against the yang-learning dynamic, we need to suspend and un-learn the learning façade as a clearing for the ever-happening study event to become visible at certain turning-points, a more spatial than temporal distinction.

If learning and studying are in flux and constant dialogue, how can we distinguish the two? As a possible heuristic (which can and perhaps ought to be abandoned at a later point), we can think of the difference between the two in relation to the logic of means and ends. Learning always concerns means and ends. Debates in learning thus take the form of two kinds of questions: (1) What ought the ends be? and (2) What are the means best suited to achieving these ends? These questions form the dialectical motor for the diversity of learning theories and practices we see today. For instance, what are the correct pedagogical methods for achieving a certain outcome? Or, inversely, what outcomes will emerge from a certain pedagogical method? The fascination with learning concerns this strong relationship between the fundamental elements of all learning: means and ends.

But the question that is not asked in learning theory and practice is why there is a relationship between means and ends at all. Here we can locate the dialectical motor underlying the diversity of study theories and practices. Once means are released from any taken-for-granted relation to ends, the means pluralize and diversify. This does not mean that ends disappear. Rather they are suspended or rendered inoperative so that the relation between means and ends suddenly becomes thematized in distinct ways that are not found in learning theories and practices.

The alternative study theories exemplify a weakening of the means-ends logic (at least as it is employed in Western institutional forms). The results are forms of learning that stress opacity and dissonance, which are distinctly undervalued in more mainstream approaches to learning discourses and practices. The result of this is not the end of education but rather the blooming of study at the end of all educational ends. On this account, the "opposition" between learning and studying is not a fixed divide so much as a glissade, or a movement of increasingly weak relations between means and ends to the extreme point where means as such appear, in their nudity, as a kind of pure educational potentiality or practice without necessary destiny or teleology.

\section{Flow of This Special Issue}

The seven pieces in this Special Issue demonstrate how this means-ends logic of learning can be further problematized by a diversity of perspectives outside the Western tradition or on its margins, and how study is perhaps best theorized from alternative locations. By 
alternative locations, we mean not only geographically diverse but also economically and culturally diverse settings.

We begin with Ford's paper on errant learning which draws out the educational implications of two significant, yet rarely pedagogically read, conceptions by Édouard Glissant and Peter Sloterdijk. In so doing, Ford links the dominance of learning and its insistence on transparency with the ongoing legacies of colonialism, and in turn proposes a new language for understanding education in the world that can no longer be explicated in traditional categories relating to space and global and intercultural relation. Next, Hans Schildermans, Joke Vandenabeele, Joris Vlieghe, and Piotr Zamojski investigate System_D, a film festival in the oppressed neighborhoods of Brussels, as an educational example to propose a concept of study practices and to rethink the notion of solidarity as being deeply entwined with matters of living together in "superdiversity." Jairo Jiménez instead looks at contemporary study practices in the university (i.e., Katholieke Universiteit Leuven) as gatherings of studying beyond the functionality of learning environments. Studying practices, Jiménez argues, are constituted by open-ended activities that are guided by present interests to things that matter, and constitute scenes where students and study-materiality join together in the event of studying.

Then we move to Petar Jandrić and Sarah Hayes's paper on postdigital we-learn, where they argue new ways are urgently needed to approach what it means to learn in the context of a global Fourth Industrial Revolution. As one such way, they refine the concept of "postdigital we-learn" as a gathering between humans and machines to re-understand the development of emancipatory and critical learning in our postdigital reality. Next comes Yusef Waghid's paper that reconceptualizes an African philosophy of higher education, teaching and learning, through the Afrian notion of ubuntu. Ubuntu ruptures the predominant learning logic that is competitive, individualistic, and focused on excellence and/or efficiency through measurement. This ubuntu philosophy, Waghid argues, provides a new understanding of social responsibility, deliberative engagement, and attentiveness to others and otherness, all conducive to enacting substantive change in, and also defending, Africa's higher education.

The last two papers turn to the Eastern landscape and connect it with the Western thought. Lewis and Xu imagine a speculative encounter between Heidegger's theorization of the fourfold and Chinese landscape paintings by Xia Gui (fl. 1195-1224) in the Song Dynasty. In so doing, they argue that Being in Heidegger's sense can best be encountered through the study of traditional Chinese landscape paintings. Distinct from a learning that concerns how to live, here "study concerns that we live - the very potentiality to live a life as it emerges within a given ontological constellation of elements." Zhao's paper turns to recalibrate study and learning beyond the educational domain as two hermeneutic principles. Drawing upon Susan Handelman's writing on literary theory, her paper correlates learning and study with seeing, hearing, and observing as three onto-epistemic modes that respectively underpin Greco-Christian, Rabbinic, and ancient Chinese exegetical traditions. Using the Greco-Christian seeing/learning and the Rabbinic hearing/study as a framework, Zhao explicates an onto-cosmological Yijing observing, proffering a study hermeneutic as a movement of observing, following, and attuning to wendao, literally put as "a crisscrossing pattern that (re-)turns with dao."

Rather than an end product, we would like to see this Special Issue as an invitation to study-with, and thus as a continuation of the struggle to find spaces and times for study within and through education and beyond and across nation-states and cultures. What remains in the shadow of learning is another, subaltern educational world irreducible to the neoliberal learning economy. By delving into and articulating the study possibilities in East, West, North, and 
South, we gesture toward new horizons for further internationalizing scholarship on study, learning, and unlearning through global dialogues for reciprocal informing.

\section{References}

Agamben, G. 2015. The use of bodies. Stanford, California: Stanford University Press.

AliRezaBeigi, S., and T.E. Lewis. 2018. Studying with the internet: Giorgio Agamben, education, and new digital technologies. Journal of Philosophy and Education 37(6): 553-566.

Arsenjuk, L., and M. Koerner. 2009. Study, students, universities: An introduction. Polygraph 21: 1-13.

Biesta, G. 2005. Against learning: Reclaiming a language for education in an age of learning. Nordisk Pedagogik 25: 54-66.

Backer, D.I., and T.E. Lewis. 2015. The studious university: a Marxist-psychoanalytic groundwork. Cultural Politics 11(3): 329-344.

D'Hoest, F., and T.E. Lewis. 2015. Exhausting the fatigue university: In search of a biopolitics of research. Ethics and Education 10(1): 49-60.

Ford, D.R. 2016. Communist study: Education for the commons. London: Lexington Books.

Ford, D.R. 2017a. Making marxist pedagogy magical: From critique to imagination, or how bookkeepers set us free. Critical Education 8(9): 1-13.

Ford, D.R. 2017b. Studying like a communist: Affect, the party, and the educational limits to capitalism. Educational Philosophy and Theory 49(5): 452-461.

Ford, D.R. 2018. Queer communist study: The sinthomostudier against the capital-learning-debt regime. Journal of Curriculum and Pedagogy 15(1): 8-23.

Ford, D.R. 2019. Politics and pedagogy in the "post-truth" era: Insurgent philosophy and praxis. London: Bloomsbury.

Ford, D.R., and W. Zhao. 2018. Toward an educational sphereology: Air, wind, and materialist pedagogy. Educational Philosophy and Theory 50(5): 528-537.

Harney, S., and F. Moten. 2013. The undercommons: Fugitive planning \& black study. Wivenhoe: Minor Compositions.

Jasinski, I., and T.E. Lewis. 2015. Community of infancy: Suspending the sovereignty of the teacher's voice. Journal of Philosophy of Education 50(4): 538-553.

Lewis, T.E. 2013. On study: Giorgio Agamben and educational potentiality. New York, NY: Routledge.

Lewis, T.E. 2017. A Marxist education of the encounter: Althusser, interpellation, and the seminar. Rethinking Marxism 29(2): 303-317.

Lewis, T.E. 2018a. Inoperative learning: A radical rewriting of educational potentialities. New York, NY: Routledge.

Lewis, T.E. 2018b. Introduction. Visual Arts Research 44(1): v-viii.

Lewis, T.E., and D. Friedrich. 2016. Educational states of suspension. Educational Philosophy and Theory 48(3): 237-250.

Rocha, S. 2015. Folk phenomenology: Education, study, and the human person. Eugene, OR: Pickwick Publications.

Murphy, M.P.A. 2020. Active learning as destituent potential: Agambenian philosophy of education and moderate steps towards the coming politics. Educational Philosophy and Theory 52(1): 66-78.

Ruitenberg, C.W. (ed.). 2017. Reconceptualizing study in educational discourse and practice. New York, NY: Routledge.

Vleighe, J. 2016. The educational meaning of tiredness: Agamben and Buytendijk on the experience of (im) potentiality. Ethics \& Education 11(3): 359-371.

Zhao, W. 2017. Review of Derek R. Ford, Communist Study: Education for the Commons. Lexington Books. 2016. Studies in Philosophy and Education, 36(2): 217-223.

Zhao, W. 2019a. Review of Tyson Lewis, Inoperative Learning: A Radical Rewriting of Educational Potentialities. London and New York: Routledge. 2018. Studies in Philosophy and Education, 38(1): 85-92.

Zhao, W. 2019b. Daoist onto-un-learning as a radical form of study: Re-imagining learning and study from an eastern perspective. Studies in Philosophy and Education 38(3): 261-273.

Zhao, W., and D.R. Ford. 2018. Re-imagining affect with study: Implications from a Daoist wind-story and yinyang movement. Studies in Philosophy and Education 37(2): 109-121.

Publisher's Note Springer Nature remains neutral with regard to jurisdictional claims in published maps and institutional affiliations. 